\title{
Refractory Disease
}

National Cancer Institute

\section{Source}

National Cancer Institute. Refractory Disease. NCI Thesaurus. Code C39752.

A disease that resists treatment. 